- A description of tunnel restoration.

- A review of clinical trials carried carried out.

- A definition of when the restoration might be used.

- The factors that need to be considered when reading the results of a clinical trial are highlighted.

\title{
The tunnel restoration
}

\author{
D. K. Ratledge ${ }^{1}$ E. A. M. Kidd ${ }^{2}$ and E. T. Treasure ${ }^{3}$
}

The aims of this paper are to give a brief history of the tunnel restoration, to describe and illustrate one way of making this restoration and to review the clinical trials of the procedure carried out to date.

\section{THE DEVELOPMENT OF THE TUNNEL RESTORATION}

In recent years the trend in restorative dentistry has been towards conservative cavity designs. The tunnel preparation is one of these, first described in $1963^{1}$ for the restoration of distal approximal surfaces of deciduous second molars. In this preparation approximal carious lesions were accessed and prepared by approaching the lesion from the occlusal aspect, instrumenting beneath the marginal ridge, but leaving it intact. The teeth were restored with a fluoride-leachable silicate cement and it was suggested that this might prevent caries developing in the mesial surface of the first permanent molar. In the 1980s the preparation was re-introduced by Hunt ${ }^{2}$ and $\mathrm{Knight}^{3,4}$ and advocated as a more conservative procedure than a conventional Class II cavity, for the treatment of primary approximal caries in posterior teeth. ${ }^{5-8}$ Glass ionomer cements, introduced by Wilson and Kent in the early $1970 \mathrm{~s},{ }^{9}$ have been described as the materials of choice for the restoration of tunnel preparations. ${ }^{10-14}$ These materials will bond to enamel and dentine and leach fluoride. ${ }^{15}$ The strongly radiopaque, silver-

${ }^{1}$ Specialist Dental Practitioner, Guildford, Surrey; ${ }^{2 *}$ Professor of Cariology, Division of Conservative Dentistry, Guy's Hospital, GKT Dental Institute, London SE1 9RT; ${ }^{3}$ Professor, Dental Public Health, Dental School, Heath Park, Cardiff CF14 4X7

*Correspondence to: Professor Edwina Kidd, Floor 25, Guy's Tower, London Bridge SE1 9RT

\section{Refereed Paper}

Received 04.07.02; Accepted 16.07.02

๑ British Dental Journal 2002; 193: 501-506 containing, glass ionomers ${ }^{16}$ have become popular although it is suggested that the occlusal access cavity should be sealed with composite resin to prevent wear of the underlying glass ionomer. ${ }^{10,12}$

The efficacy of caries removal is perhaps a cause for concern bearing in mind the limited access afforded by the preparation. Some laboratory studies have shown this to be a potential problem ${ }^{17-19}$ but the only work to assess caries removal in vivo is more reassuring. ${ }^{20,21}$ A microbiological study involving removal of samples of dentine before and after cavity preparation in tunnel and control Class II cavity preparations showed significant reductions in bacterial counts after cavity preparation in both groups.

The terminology used to describe tunnel restorations is slightly confusing. Some authors describe an internal tunnel preparation which is actually a Class I cavity. Here the approximal enamel is retained because there is no macroscopically observable cavitation. A partial tunnel preparation extends onto the approximal surface into a macroscopically observable cavitation or into an area where the enamel has disintegrated during cavity preparation. The enamel is carefully smoothed around the opening leaving some demineralised enamel adjacent to the filling. In the total tunnel preparation it is claimed that all demineralized enamel is removed.

\section{CLINICAL TECHNIQUE}

The clinical technique for a cavitated lesion is described on the next page. ${ }^{20,21} \mathrm{We}$ would suggest that lesions that are not cavitated should be managed by preventive treatment; plaque control with dental floss and a fluoridated dentifrice. The demineralised dentine in non-cavitated lesions is minimally infected. ${ }^{21}$

\section{CLINICAL TRIALS}

Table 1 lists the clinical studies of the tunnel restoration that have been carried out on permanent teeth. The search methods used to find these studies were a Medline search of English literature from the 1960s, to mid-2000 using the keywords, 'tunnel restoration' and, 'tunnel cavity preparation' followed by a careful check of all relevant references at the end of these papers. Sixteen studies were found. Three of these $e^{3,32,33}$ were excluded because the number of restorations inserted at baseline was not clear. This information is fundamental if the success or failure of a technique is to be evaluated. One preliminary report ${ }^{34}$ of a study later described in further detail ${ }^{28}$ was also eliminated. The review will now comment on the design of the remaining 12 studies before attempting to summarize their findings.

\section{RANDOMISED CONTROLLED CLINICAL TRIALS}

Only the first four studies, ${ }^{20,23-25}$ are designed as clinical trials involving a control material. The inclusion of a control group is important in clinical trials that evaluate a new technique or material. This design enables the researcher to comment on how the results of the new method compare to 'standard practice' which in the case of the operative management of approximal caries, would access the lesion 


\section{THE CLINICAL TECHNIQUE}

Cavitated lesions are likely to progress because use of dental floss will not remove plaque from within the cavity. The restoration seeks to restore the integrity of the tooth surface so that plaque control may be re-established. Magnification is helpful when doing this restoration. To be sure that the lesion is cavitated and to improve visual access for operative dentistry it is useful to separate teeth by placing an orthodontic elastic separator (American Orthodontics Corporation Wisconsin, USA). Figure 1 shows the separator in position and Figure 2 shows the small interproximal space created on removal of the separator 1 week later. The dentist can now gently use a probe, running it parallel to the tooth surface, to check a cavity is actually present.

Having obtained local anaesthesia a rubber dam is placed. Access is made with a tungsten Carbide (Jet 330) bur. The entry point of the bur is in the occlusal fossa about $2 \mathrm{~mm}$ away from the marginal ridge. The bur is angled axially through the enamel to produce an ovoid access cavity but once dentine is reached the bur is angled towards the carious lesion (Fig. 3). Further cavity preparation is carried out with slow speed round burs. The cavity is considered to be caries-free when the dentine feels hard to a straight probe. A matrix band is placed and wedged (Fig. 4).
The tooth is conditioned with the acid conditioner supplied with the glass ionomer cement for 10 seconds and the cavity washed and dried (Fig. 5). The glass ionomer cement is mixed according to the manufacturer's instructions and carefully inserted into the cavity and condensed. Once the glass ionomer has set, the occlusal portion, approximately $1 \mathrm{~mm}$ in depth, is removed with slow round burs (Fig. 6). The cavity margins are now etched with ortho-phosphoric acid for 30 seconds. After washing and drying unfilled composite bonding resin is applied to the surface, gently air dried and light-cured for 10 seconds. The access cavity is restored with composite resin (Fig. 7). The matrix band is removed and Softlex polishing strips (3M) are used to finish the glass ionomer at the approximal surface. The tooth is washed and dried and a further layer of unfilled resin is placed occlusally and approximally and light cured for 10 seconds. After removing the rubber dam, the occlusal contacting surfaces are checked for interferences. Oral hygiene instruction is given, particularly the need for dental floss. The restoration is reviewed clinically in 6 months and clinically and radiographically in a year.
Fig. 1 An elastic separator is placed adjacent to the mesial surface of the upper second premolar tooth which is to be restored

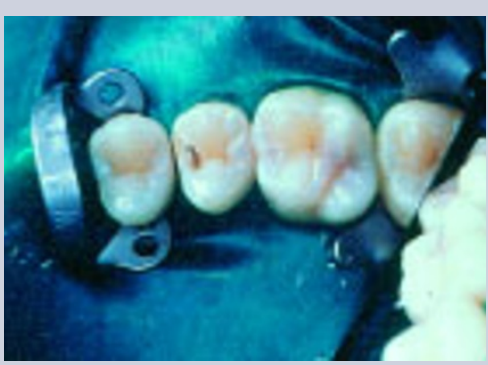

Fig. 3 Access to the approximal caries is gained via the occlusal fossa leaving the marginal ridge intact

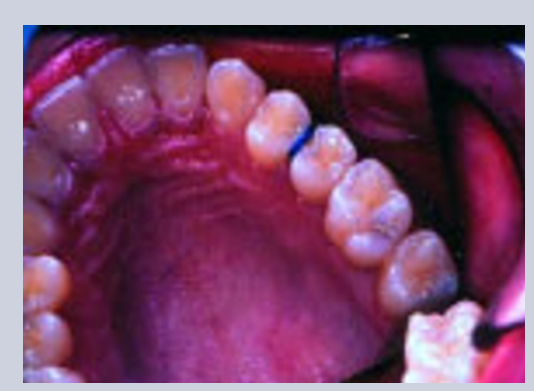

Fig. 2 A small interproximal space is created on removal of the separator 1 week later

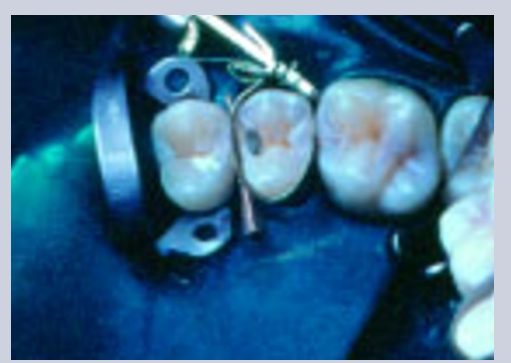

Fig. 4 Following cavity preparation a matrix band is secured around the tooth

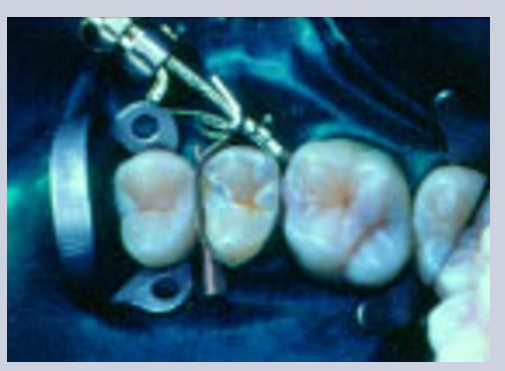

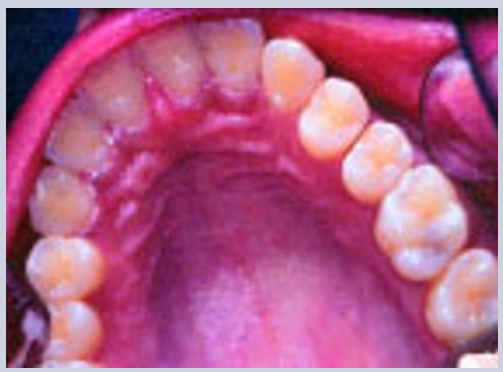

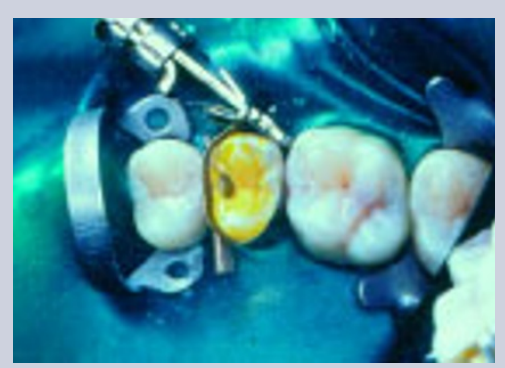

Fig. 5 Twenty five percent polyacrylic acid is applied for 10 seconds and the cavity is washed and dried

Fig. 7 The tooth is restored with composite resin




by removing the marginal ridge. In designing a clinical trial care should be taken to randomly assign subjects into experimental and control groups that differ only in terms of the intervention. This avoids bias in the selection of the two groups. ${ }^{35}$ To give a relevant example it should not be possible for the operator to place a patient into an experimental or a control group on the basis of the size of the lesion on radiograph.

Many of the studies listed in Table 1 are large and carried out in a community setting. It is therefore surprising that so few studies have been designed with controls since there appeared to be no shortage of patients. Ironically the first four studies in the table, which were controlled, have rather small numbers of patients. It should also be noted that the ideal design of a clinical trial is double blind in that neither the dentist nor the patient are aware of whether the patient belongs to the experimental or the control group. However, this design is not possible when comparing a tunnel restoration which preserves the marginal ridge with a standard Class II restoration which removes it.

\section{WHAT CONSTITUTES FAILURE? THE CHOICE OF OBSERVERS}

A systematic review on the longevity of restorations has recently been reported. ${ }^{36}$ Those responsible for this work have also reflected on the problems of designing a clinical trial to assess restoration longevity. ${ }^{37}$ Much thought was given as to how restoration failure could be determined from the literature. Two approaches were possible: the first was to accept that if a restoration was actually replaced it had failed. This pragmatic attitude accepts the dentist's decision as valid. The alternative approach is to accept that a restoration had failed when the decision to replace it was based on clearly defined criteria. This latter approach was chosen in the systematic review because it was the objective one. However, this decision inevitably excluded all studies that examined the longevity of restorations placed in practice where the criteria for replacement were not given other than a dentist's decision to replace.

All but one ${ }^{26}$ of the studies listed gave the criteria used to assess failure. An ideal protocol is one that can be copied by another group. To give an example: it was considered acceptable to say that secondary caries was considered a valid failure criterion, but it is even better to describe exactly the clinical and radiographic appearances that constitute this diagnosis.

Objective criteria are important because the results of a clinical trial can be biased by the opinions of the observers. This is particularly likely in these studies because the observer cannot be 'blind' as to which group the restoration is in. Thus the observer might wish the new technique to perform well and this is even more likely if the observer is evaluating his or her own work. This may well have been relevant to some of the studies listed in Table 1 where dentists apparently assessed their own work. The inclusion of multiple assessors is preferable although this introduces its own difficulties, as their assessments may not be reproducible with each other. In a well planned trial a number (usually 10\%) of observations are repeated and statistical tests used to check both intra- and inter-examiner reproducibility. None of the studies in Table 1 took this approach although several used multiple, calibrated examiners thus making a real attempt to standardize assessment. Furthermore, good studies ensure the data are clearly presented according to international standards. This ensures appropriate conclusions can be drawn but in the present work it was difficult to unravel the relevant data from the material presented.

\section{SETTING}

Many of the studies listed in Table 1 were carried out in a community setting or in general practice. Thus the new restoration was placed and evaluated in the setting in which it will generally be used. Reference to Table 1 shows that in only seven studies was there more than one operator involved. Multiple operators is the clinically realistic situation but this introduces another variable. Now the results may be influenced by the skill of the dentist. For this reason the effect of the operator is sometimes taken into account in analysis. ${ }^{31}$

\section{CARIES ACTIVITY OF PARTICIPANTS}

Most restorative dentistry in adult patients is replacement of failed restorations and in general practice, a dentist's diagnosis of secondary caries is the most common reason to replace a restoration. ${ }^{38}$ However, when randomised clinical trails of restorations are carried out, secondary caries is rarely a problem. ${ }^{39}$ It is impossible to know whether these differences between routine practice and clinical trials reflect an actual difference in the caries risk status of the patients in the two settings, or poor diagnosis of secondary caries, or poor restorative technique encouraging this failure. In one study listed in Table 1 caries active patients were specifically selected ${ }^{23}$ and in two others the effect of caries rate on survival times was examined. 22,31

\section{DROP OUT RATE}

The number of patients completing a clinical trial is important information. Loss of subjects might reflect systematic differences between the groups because one of the treatments was ineffective or uncomfortable in comparison with the other. Thus loss of subjects may bias results (attrition bias) and this inevitably means that conclusions are reached on the basis of fewer assessments than was originally planned. Reference to Table 1 shows the drop out rates and the loss of subjects was often considerable ranging from 0 to $60 \%$. This might not matter if the research could show the drop out was random but this has not been addressed in these studies. It is equally possible that the high drop out reflects failure of the restorations.

\section{RESULTS OF THE CLINICAL TRIALS PRESENTED IN TABLE 1}

From the previous discussion it is obvious that many of the studies listed in Table 1 are methodologically flawed by a lack of controls and high drop out rates. The only studies considered acceptable by the systematic review ${ }^{36}$ on the longevity of restorations, were controlled or a prospective series of cases where specific criteria were given on why restorations were to be replaced. Chadwick et al. $(2001)^{37}$ produced a hierarchy of study designs. Their paper concluded that the ideal study design to assess the longevity of restorations would be multicentre, multioperator studies for assessment periods greater than 10 years. While the logic of the approach is obvious, achieving it in a primary care, realistic setting seems almost unattainable! None of the studies in Table 1 fulfil these criteria.

The length of the trial seems particularly important in the tunnel restoration. Two papers $^{25,34}$ show reasonable results at 3 years but much higher failure rates at 5 years with respect to secondary caries. Since, secondary caries is primary caries at the margin of a restoration this is not surprising. It would seem the tunnel restoration is contra-indicated in any patient with a high caries activity.

An obvious question is how does the longevity of the tunnel restoration compare to that of amalgam and composite posterior restorations? Since there is only one controlled study lasting longer than 5 years ${ }^{25}$ this information is not available from the literature. However, a systematic review of the longevity of restorations ${ }^{36}$ concluded that at 10 years less than 10\% of amalgams had been replaced, and amalgam survived significantly better than composite. In the light of this the 
Table 1 Clinical studies of tunnel restorations in permanent teeth. Only four studies used controls and these are highlighted.

\begin{tabular}{|c|c|c|c|c|c|c|c|c|}
\hline Author & $\begin{array}{l}\text { Duration } \\
\text { of study }\end{array}$ & $\begin{array}{l}\text { Age group and } \\
\text { setting }\end{array}$ & $\begin{array}{l}\text { Number of } \\
\text { tunnel } \\
\text { restorations } \\
\text { and operators } \\
\text { involved }\end{array}$ & $\begin{array}{l}\text { Restorative } \\
\text { material }\end{array}$ & $\begin{array}{l}\text { Number of } \\
\text { controls and } \\
\text { material used }\end{array}$ & $\begin{array}{l}\text { Number of } \\
\text { patients and } \\
\text { restorations } \\
\text { assessed }\end{array}$ & $\begin{array}{l}\text { Drop-out } \\
\text { rate \% of } \\
\text { restorations }\end{array}$ & Result \\
\hline $\begin{array}{l}\text { Svanberg } \\
(1991)^{23} \\
\text { Sweden }\end{array}$ & 3 years & $\begin{array}{l}8 \text { caries active } \\
\text { adolescents aged } \\
13-16 \text { years } \\
\text { treated in } \\
\text { community } \\
\text { setting }\end{array}$ & $\begin{array}{l}18 \text { restorations } \\
\text { performed by } \\
1 \text { operator }\end{array}$ & $\begin{array}{l}\text { Ketac Silver } \\
\text { (No occiusal } \\
\text { composite) }\end{array}$ & $\begin{array}{l}18 \text { contralateral } \\
\text { class II } \\
\text { amalgam } \\
\text { restorations in } \\
\text { the same group } \\
\text { of patients }\end{array}$ & $\begin{array}{l}36 \text { restorations } \\
\text { in } 18 \text { patients }\end{array}$ & $0 \%$ & $\begin{array}{l}\text { After } 3 \text { years } 1 \text { tunnel } \\
\text { restoration failed due to } \\
\text { fracture of marginal ridge } \\
\text { and } 3 \text { amalgams failed due } \\
\text { to recurrent caries. }\end{array}$ \\
\hline $\begin{array}{l}\text { Wilkie et al. } \\
(1993)^{24} \\
\text { Australia }\end{array}$ & 2 years & $\begin{array}{l}26 \text { adults (no } \\
\text { specified age } \\
\text { range) treated in } \\
\text { dental hospital }\end{array}$ & $\begin{array}{l}42 \text { tunnel } \\
\text { restorations } \\
\text { placed in } \\
\text { permanent teeth } \\
\text { by } 2 \text { operators }\end{array}$ & $\begin{array}{l}\text { Ketac Silver } \\
\text { (No occlusal } \\
\text { composite) }\end{array}$ & $\begin{array}{l}16 \text { class II } \\
\text { amalgams } \\
28 \text { class II } \\
\text { composite }\end{array}$ & $\begin{array}{l}42 \text { tunnel } \\
13 \text { amalgam } \\
20 \text { composite }\end{array}$ & $\begin{array}{l}25 \% \text { control } \\
0 \% \text { test }\end{array}$ & $\begin{array}{l}\text { All amalgams successful } \\
\text { after } 2 \text { years } \\
7 \% \text { of composites failed } \\
\text { due to fracture }(n=2) \\
48 \% \text { of GIC tunnel } \\
\text { restorations failed due to } \\
\text { wear. None failed due to } \\
\text { secondary caries or } \\
\text { fracture. }\end{array}$ \\
\hline $\begin{array}{l}\text { Ratledge } \\
(1999)^{20}\end{array}$ & & $\begin{array}{l}32 \text { patients, } \\
\text { mainly young } \\
\text { adults, treated in } \\
\text { dental hospital }\end{array}$ & $\begin{array}{l}32 \text { restorations } \\
\text { placed by one } \\
\text { operator }\end{array}$ & $\begin{array}{l}\text { Shofu Hi- } \\
\text { Dense glass } \\
\text { ionomer with } \\
\text { occiusal } \\
\text { composite }\end{array}$ & $\begin{array}{l}28 \text { class II } \\
\text { amalgam } \\
\text { restorations }\end{array}$ & $\begin{array}{l}19 \text { patients } \\
17 \text { tunnel } \\
17 \text { amalgam }\end{array}$ & $\begin{array}{l}60 \% \text { after } \\
\text { one year }\end{array}$ & $\begin{array}{l}\text { All satisfactory after } 1 \\
\text { year. }\end{array}$ \\
\hline $\begin{array}{l}\text { Lumley and } \\
\text { Fisher } \\
(1995)^{25} \\
\text { UK }\end{array}$ & $\begin{array}{l}5-10 \\
\text { years }\end{array}$ & $\begin{array}{l}25 \text { adults aged } \\
19-45 \text { years } \\
\text { treated in dental } \\
\text { hospital }\end{array}$ & $\begin{array}{l}33 \text { restorations } \\
\text { I operator }\end{array}$ & $\begin{array}{l}\text { Ketac Fil and } \\
\text { Ketac Silver } \\
\text { (no occlusal } \\
\text { composite) }\end{array}$ & $\begin{array}{l}14 \text { minimal } \\
\text { Almquist class } \\
\text { II restorations } \\
\text { using Sybralloy } \\
\text { in the same } \\
\text { group of } \\
\text { patients }\end{array}$ & $\begin{array}{l}33 \text { restorations } \\
\text { in } 25 \text { patients } \\
\text { and } 14 \\
\text { controls in } \\
\text { variable } \\
\text { periods } \\
5-10 \text { years }\end{array}$ & $0 \%$ & $\begin{array}{l}\text { All satisfactory after } \\
3 \text { years. } \\
\text { After } 5 \text { years } 25 \% \text { GICs } \\
\text { and } 10 \% \text { cermets failed } \\
\text { due to recurrent caries and } \\
\text { fracture of the marginal } \\
\text { ridges. All controls } \\
\text { successful }\end{array}$ \\
\hline $\begin{array}{l}\text { Hunt } \\
(1984)^{2} \\
\text { USA }\end{array}$ & 2 years & $\begin{array}{l}\text { General practice, } \\
\text { age not stated }\end{array}$ & $\begin{array}{l}20 \text { restorations } \\
\text { in } 10 \text { patients } \\
\text { placed by } 1 \\
\text { operator }\end{array}$ & $\begin{array}{l}\text { Non- } \\
\text { radiopaque } \\
\text { glass-ionomer }\end{array}$ & $\begin{array}{l}\text { None } \\
\text { (no occlusal } \\
\text { composite) }\end{array}$ & $\begin{array}{l}20 \text { restorations } \\
\text { in } 10 \text { patients }\end{array}$ & $0 \%$ & $100 \%$ successful \\
\hline $\begin{array}{l}\text { Ehrlich and } \\
\text { Yaffe } \\
(1987)^{26} \\
\text { Israel }\end{array}$ & 2.5 years & $\begin{array}{l}78 \text { adults aged } 18 \\
-35 \text { years treated } \\
\text { in dental hospital }\end{array}$ & $\begin{array}{l}154 \text { restorations } \\
1 \text { operator }\end{array}$ & amalgam & None & Not given & 0\% implied & $\begin{array}{l}5 \text { failed due to fracture of } \\
\text { marginal ridge after } 6 \\
\text { months, } 1 \text { after } 18 \text { months } \\
\text { (total } 4 \% \text { failure rate). } \\
\text { None failed due to } \\
\text { recurrent caries. }\end{array}$ \\
\hline $\begin{array}{l}\text { Strand et al. } \\
(1996)^{27} \\
\text { Norway }\end{array}$ & 3 years & $\begin{array}{l}\text { Children and } \\
\text { adults aged } 10 \text { - } \\
30 \text { years treated in } \\
\text { community } \\
\text { setting }\end{array}$ & $\begin{array}{l}230 \text { restorations } \\
\text { in } 117 \text { patients } \\
\text { performed by } \\
4 \text { dentists }\end{array}$ & $\begin{array}{l}\text { Ketac Silver } \\
\text { (No occlusal } \\
\text { composite) }\end{array}$ & None & $\begin{array}{l}161 \\
\text { restorations in } \\
85 \text { patients }\end{array}$ & $\begin{array}{l}30 \% \text { after } \\
3 \text { years }\end{array}$ & $\begin{array}{l}14 \% \text { replaced due to } \\
\text { fracture of marginal ridge } \\
16 \% \text { replaced due to } \\
\text { secondary caries } \\
\text { Radiolucencies adjacent to } \\
\text { restoration were observed } \\
\text { in remaining } 34 \%\end{array}$ \\
\hline $\begin{array}{l}\text { Hasselrot } \\
(1998)^{28} \\
\text { Sweden }\end{array}$ & 7 years & $\begin{array}{l}193 \text { teenagers and } \\
\text { young adults } \\
\text { treated in } \\
\text { community } \\
\text { setting }\end{array}$ & $\begin{array}{l}282 \text { restorations } \\
\text { in } 208 \text { patients } \\
1 \text { operator }\end{array}$ & $\begin{array}{l}\text { Ketac Silver } \\
\text { Conventional } \\
\text { GIC plus } \\
\text { occlusal } \\
\text { composite }\end{array}$ & None & $\begin{array}{l}\text { All at } 18 \\
\text { months } \\
124 \text { at } 7 \text { years }\end{array}$ & $\begin{array}{l}0 \% \text { at } \\
18 \text { months } \\
57 \% \text { at } \\
7 \text { years }\end{array}$ & $\begin{array}{l}7 \% \text { annual failure rate with } \\
\text { a } 50 \% \text { survival time of } \\
6 \text { years. Overall failures } \\
\text { due to: } \\
\text { recurrent caries } 40 \% \\
\text { fracture of marginal ridge } \\
41 \% \text { cavitation of } \\
\text { approximal enamel } 19 \% \\
\text { ontinued on the next page }\end{array}$ \\
\hline
\end{tabular}


Table 1 Contd Clinical studies of tunnel restorations in permanent teeth. Only four studies used controls and these are highlighted.

\begin{tabular}{|c|c|c|c|c|c|c|c|c|}
\hline Author & $\begin{array}{l}\text { Duration } \\
\text { of study }\end{array}$ & $\begin{array}{l}\text { Age group and } \\
\text { setting }\end{array}$ & $\begin{array}{l}\text { Number of } \\
\text { tunnel } \\
\text { restorations and } \\
\text { operators } \\
\text { involved }\end{array}$ & $\begin{array}{l}\text { Restorative } \\
\text { material }\end{array}$ & $\begin{array}{l}\text { Number of } \\
\text { controls and } \\
\text { material used }\end{array}$ & $\begin{array}{l}\text { Number of } \\
\text { patients and } \\
\text { restorations } \\
\text { assessed. }\end{array}$ & $\begin{array}{l}\text { Drop-out } \\
\text { rate \% of } \\
\text { restorations }\end{array}$ & Result \\
\hline $\begin{array}{l}\text { Holst and } \\
\text { Brännström } \\
(1998)^{29} \\
\text { Sweden }\end{array}$ & 3 years & $\begin{array}{l}\text { Children and } \\
\text { adults treated in } \\
\text { community } \\
\text { setting number of } \\
\text { patients not stated }\end{array}$ & $\begin{array}{l}302 \text { tunnel } \\
\text { restorations } \\
\text { placed by } 17 \\
\text { operators }\end{array}$ & $\begin{array}{l}\text { Ketac Silver } \\
\text { (no occlusal } \\
\text { composite) }\end{array}$ & None & $\begin{array}{l}302 \\
\text { restorations } \\
\text { after } 3 \text { years }\end{array}$ & $\begin{array}{l}9.4 \% \text { after } \\
3 \text { years }\end{array}$ & $\begin{array}{l}\text { 93\% successful after } 1 \text { year } \\
90 \% \text { successful after } 2 \text { years } \\
84 \% \text { successful after } 3 \text { years } \\
\text { Overall } 8 \% \text { failed due to } \\
\text { caries and } 6 \% \text { due to } \\
\text { fracture of the marginal } \\
\text { ridge. }\end{array}$ \\
\hline $\begin{array}{l}\text { Pilebro et al. } \\
(1999)^{30} \\
\text { Sweden }\end{array}$ & 3 years & $\begin{array}{l}272 \text { children and } \\
\text { adults } \\
\text { (mean age - } 19 \\
\text { years) treated in } \\
\text { community } \\
\text { setting }\end{array}$ & $\begin{array}{l}374 \text { tunnel } \\
\text { restorations } \\
\text { placed by } 12 \\
\text { operators }\end{array}$ & $\begin{array}{l}\text { Ketac Silver } \\
\text { (no occlusal } \\
\text { composite) }\end{array}$ & None & $\begin{array}{l}305 \\
\text { restorations in } \\
207 \text { patients at } \\
3 \text { years }\end{array}$ & $\begin{array}{l}9 \% \text { after } \\
1 \text { year } \\
17 \% \text { after } \\
2 \text { years } \\
30 \% \text { after } \\
3 \text { years }\end{array}$ & $\begin{array}{l}\text { At baseline } 14 \% \text { showed } \\
\text { defect on BW and } 8 \% \\
\text { signs of non-excavated } \\
\text { dentine caries. } \\
305 \text { restorations reviewed } \\
\text { after } 3 \text { years, } 14 \% \\
\text { fractured and } 14 \% \text { had } \\
\text { secondary caries }\end{array}$ \\
\hline $\begin{array}{l}\text { Strand et al. } \\
(2000)^{22} \\
\text { Norway }\end{array}$ & $\begin{array}{l}54 \\
\text { months }\end{array}$ & $\begin{array}{l}252 \text { patients aged } \\
9-20 \text { years in } \\
\text { community }\end{array}$ & $\begin{array}{l}420 \text { restorations } \\
\text { placed by } 12 \\
\text { operators }\end{array}$ & $\begin{array}{l}\text { Ketac Silver } \\
\text { (no occlusal } \\
\text { composite) }\end{array}$ & None & $\begin{array}{l}302 \\
\text { restorations in } \\
179 \text { patients }\end{array}$ & $\begin{array}{l}28 \% \\
\text { between 24- } \\
54 \text { months }\end{array}$ & $\begin{array}{l}\text { 57\% satisfactory at } \\
\text { variable periods between } \\
24 \text { and } 54 \text { months. High } \\
\text { levels of caries activity } \\
\text { and internal type } \\
\text { preparations gave poorest } \\
\text { prognosis. }\end{array}$ \\
\hline $\begin{array}{l}\text { Nicolaisen } \\
\text { etal. } \\
(2000)^{31} \\
\text { Norway }\end{array}$ & $\begin{array}{l}76 \\
\text { months }\end{array}$ & $\begin{array}{l}173 \text { patients } \\
\text { over } 16 \text { years in } \\
\text { community } \\
\text { setting }\end{array}$ & $\begin{array}{l}355 \text { restorations } \\
\text { placed by } \\
7 \text { operators }\end{array}$ & Not reported & None & $\begin{array}{l}182 \\
\text { restorations in } \\
94 \text { patients }\end{array}$ & $\begin{array}{l}49 \% \\
\text { periods up } \\
\text { to } 76 \\
\text { months }\end{array}$ & $\begin{array}{l}90 \% \text { satisfactory after } \\
3 \text { years } \\
35 \% \text { satisfactory after } \\
5 \text { years } \\
\text { Caries activity and } \\
\text { operator had significant } \\
\text { effects on survival times. }\end{array}$ \\
\hline
\end{tabular}

longevity of the tunnel restoration is disappointing.

In summary, we would suggest the following comments can be made about the tunnel restoration:

- Fracture of the marginal ridge can be a problem.

- Secondary caries is an important cause of failure and this becomes apparent in studies after 3 years. This probably reflects the slowly progressing nature of the carious process.

- Secondary caries is a particular problem when this restoration is placed in caries active patients.

We would suggest that the tunnel restoration may have a limited life expectancy and should only be used in patients with low caries activity.

1. Jinks G M. Fluoride-impregnated cements and their effect on the activity of interproximal caries. J Dent Child 1963: 30: 87-92.

2. Hunt PR. A modified class II cavity preparation for glass ionomer restorative materials. Quintessence Int 1984; 10: 1011-1018.

3. Knight $\mathrm{GM}$. The use of adhesive materials in the conservative restoration of selected posterior teeth.
Austr Dent J 1984; 29: 324-331.

4. Knight G M. The tunnel restoration. Dent Outlook 1984; 10: 53-57.

5. Howe L C. Minimal tooth preparation techniques for restorations with adhesive materials. Dent Update 1989: 12: 418-425.

6. Hunter A R, Hunter A J. The class II caries lesion. Part 2. Alternative direct cavity preparations. New Zealand Dent J 1989: 85: 116-121.

7. Hunt PR. Microconservative restorations for approximal carious lesions. J Am Dent Ass 1990; 120: 37-40.

8. Papa J, Wilson P R, Tyas M J. Tunnel restorations: A review. J Esth 1992; 4: 4-9.

9. Wilson A D, Kent B E. A new translucent cement for dentistry. Br Dent J 1972; 132: 133-135.

10. Croll T P. Glass ionomer-silver cermet bonded composite resin Class II tunnel restorations. Quintessence Int 1988; 19: 533-539.

11. McLean J W. Limitations of posterior composite resins and extending their use with glass ionomer cements. Quintessence Int 1987; 18: 517-529.

12. McLean J W. Clinical applications of glass-ionomer cements. Op Dent 1992; Suppl 5: 184-190.

13. Tay W M, Lynch E. Glass-ionomer cements - Clinical usage and experience. Dent Update 1990; 17: 51-56.

14. Mount G J. Clinical placement of modern glass ionomer cements. Quintessence Int 1993; 24: 99-107.

15. Forsten L. Fluoride release and uptake by glass ionomers. Scand J Dent Res 1991; 99: 241-245.

16. McLean J W, Gasser 0 . Glass-cermet cements. Quintessence Int 1985; 16:333-343.

17. Strand G V. Tveit A B. Effectivenesss of caries removal by the partial tunnel preparation method. Scand J Dent Res 1993; 101: 270-273.
18. Strand GV, Tveit A B, Espelid L. Variations among operators in the performance of tunnel preparations in vitro. Scand J Dent Res 1994; 102: 151-155.

19. Strand GV Tveit A B, Eide G E. Cavity design and dimensions of tunnel preparations versus composite resin class II preparations. Acta Odont Scand 1995; 53: 217-221.

20. Ratledge D K. A clinical and laboratory investigation of the tunnel restoration. PhD Thesis, University of London 1999.

21. Ratledge D K, Kidd E A M, Beighton D. A clinical and microbiological study of approximal carious lesions. Part 2: Efficacy of caries removal following tunnel and Class II cavity preparation. Caries Res 2001; 35: 8-11.

22. Strand $G V$, Nordb $\emptyset H$, Leirskar J, von der Fehr FR, Eide $\mathrm{G}$ E. Tunnel restorations placed in routine practice and observed for 24 to 54 months. Quintessence Int 2000; 31: 453-460.

23. Svanberg M. Class II amalgam restorations, glassionomer tunnel restorations, and caries development on adjacent tooth surfaces: A 3-year clinical study. Caries Res 1991; 26: 315-318.

24. Wilkie R, Lidums A, Smales R. Class II glass ionomer cermet tunnel, resin sandwich and amalgam restorations over 2 years. Am J Dent 1993; 6: 181-184.

25. Lumley PJ, Fisher F J. Tunnel restorations: a long-term pilot study over a minimum of five years. J Dent 1995; 23: 213-215.

26. Ehrlich J, Yaffe A. A modified cavity preparation for restoring interproximal caries. Compend Contin Educ Dent 1987; 8: 62-65.

27. Strand G V, Nordbø $H$, Tveit A B, Espelid I, Wikstrand, Eide G E. A 3-year clinical study of tunnel 
restorations. Eur J Oral Sci 1996; 104: 384-389.

28. Hasselrot L. Tunnel restorations in permanent teeth. A 7 year follow up study. Swed Dent J 1998; 22: 1-7.

29. Holst $D$, Brännström $M$. Restoration of proximal dentine lesions with the tunnel technique. Swed Dent J 1998; 22: 143-148.

30. Pilebro C E, Dijken J W, Stenberg R. Durability of tunnel restorations in general dental practice a 3-year multi-centre study. Acta Odont Scand 1999; 57:35-39.

31. Nicolaisen S, von der Fehr FR, Lunder N, Thomsen I. Performance of tunnel restorations at 3-6 years. J Dent 2000; 28: 383-387.

32. Knight $\mathrm{GM}$. The tunnel restoration - nine years of clinical experience using encapsulated glass ionomer cements. Case report. Austral Dent J 1992; 37: 245-251.

33. Pyk N, Mejàre I. Tunnel restorations. Influence of some of the clinical variables on the success rate. Acta Odont Scand 1999; 57: 149-154.

34. Hasselrot L. Tunnel restorations. A $31 \frac{1}{2}$ year follow-up study of class I and class II restorations in permanent and primary teeth. Swed Dent J 1993; 17: 173-182.

35. Moles D R, dos Santos Silva I. Causes, associations and evaluating evidence; can we trust what we read? Evidence-Based Dent 2000; 2: 75-78.

36. The University of York NHS Centre for Reviews and Dissemination. Dental Restorations: what type of filling? Effective Health Care:1999; 5: Nos 2.

37. Chadwick B, Treasure E, Dummer P, Gilmour A, Jones
R, Phillips C, Stevens J, Rees J, Richmond S. Challenges with studies investigating longevity of dental restorations - a critique of a systematic review. J Dent 2001; 29: 155-161.

38. Akerboom H B, Advokaat J G, van Amerongen W E, Borgmeijer P. Long term evaluation and rerestorations of amalgam restorations. Community Dent Oral Epidemiol 1993; 21: 45-48.

39. Letzel $H$, van't Hof M A, Marshall G W, Marshall S J. The influence of the amalgam alloy on the survival of amalgam restorations: A secondary analysis of multiple controlled clinical trials. J Dent Res 1997; 76: 1787-1798. 